\title{
Izaak z Trok, syn Abrahama, karaimski uczony z XVI wieku
}

\author{
RAFAŁ WITKOWSKI
}

Gmina karaimska w Trokach, najstarsza i najważniejsza spośród gmin położonych w granicach dawnego Wielkiego Księstwa Litewskiego, może poszczycić się autorem polemicznych traktatów - Izaakiem, którego imię odnaleźć można w wielu encyklopediach ${ }^{1}$.

*Pragnę podziękować p. Goldzie Akhiezer, z którą rozmawiałem o Izaaku z Trok w Polsce i Izraelu. Jej sugestie zwróciły moją uwagę na niektóre aspekty jego życia i działalność; osobne słowa podziękowania kieruję pod adresem p. Marioli Abkowicz.

1Por.: Johannes Christophor Wolf, Bibliotheca hebraea, t. 1 Hamburgi 1715, s. 641643; t. 3, Hamburgi 1727, s. 544-547; t. 4, Hamburgi 1733, s. 639-645; A. Geiger, Isaak Troki. Ein Apologet des Judenthums am Ende des 16. Jahrhunderts, w: Breslauer Jahrbuch für das Jahr 5614, Breslau 1853 (przedruk w Abraham Geiger, Nachgelassene Schriften, hrsg. von L. Geiger, Bd. 3, Berlin 1876, s. 178-223 (reprint, New York 1980); J.H.R. Biesenthal, Der Karait Isac Trocki, Jeschurun, Jg. 2 (1860), s. 28-31, 57-67, 357-363; Jg. 3 (1861), s. 13-21, 44-50, 69-76, 101-106; A. Kraushar, Historya Żydów w Polsce, t. 2, 1866, s. 266-267; H. Schwabedissen, H.L. Strack, Isaak Troki und seine Zeit, Nathanel. Zeitschrift für die Arbeit der Evangelischen Kirche aus Israel, t. 5 (1889), s. 52-69; Miksa Szabolcsi, Izsak ben Abraham Troki Emunaja nyoman osszeallitotta es bevezetessel ellatta, Budapest 1908; S. Dubnow, Weltgeschichte des jüdischen Volkes, Bd. 6: Die Geschichte des jüdischen Volkes in der Neuzeit, Frakfurt am Main 1927, s. 380-383; M. Waxmann, A History of Jewish Literature, vol. 2 (1933), s. 449-451; S. Szyszman, Die Karäer in OstMitteleuropa, Zeitschrift für Ostforschung, Jg. 6 (1957), s. 24-54; E.L. Dietrich, Das jüdisch -christliche Religionsgespräch am Ausgang des 16. Jahrhunderts nach dem Handbuch des R. Isaak Troki, Jud, Jg. 14 (1958), s. 1-39; S.W. Baron, A Social and Religious History of the Jews, New York 1976, s. 8-9; N. Schur, History of the Karaites, Frankfurt am Main 1992, s. 101-112; M. Greenbaum, The Jews of Lithuania. A History of a remarkable Community 1316-1945, Jerusalem 1995, s. 155-159; R. Sievert, Isaak ben Abraham aus Troki im christlich-jüdischen Gespraäch der Reformationszeit, Münster 2005 (Münsteraner judaistische Studien, Bd. 17); R.H. Popkin, Disputing Christianity. The 400-year-old debate over Rabbi Isaac ben Abraham of Troki's classic arguments, Amherst, N.Y., 2007 (tam najnowsza bibliografia); por. jego biogramy: W. Zajączkowski, Izaak syn Abrahama $z$ Trok (1533-1594), w: -Polski Słownik Biograficzny, t. 10 (1962), z. 2, s. 193-194; Encyclopedia Judaica, vol. 15, Jerusalem 1971, s. 1403-1404; The Universal Jewish Encyclo- 
Nowa religia, zrodzona w VIII w. na terenie starożytnej Mezopotamii, początkowo rozwijała się w rejonie Bliskiego Wschodu. Nadal dyskutowana jest kwestia przyjęcia przez Chazarów, zamieszkujących wówczas Półwysep Krymski, wyznania karaimskiego i rozprzestrzenianie się tego wyznania wśród tureckojęzycznej ludności. Bez wątpienia Karaimi, którzy na przełomie XIV i XV w. przybyli na ziemie Wielkiego Księstwa Litewskiego, wywodzili się od wyznawców karaimizmu zamieszkałych na Krymie ${ }^{2}$. W dokumentach łacińskich z tego okresu byli określani często jako „Żydzi troccy”, co wskazywało jednoznacznie na miejsce ich osiedlenia. Według badań językoznawczych i antropologicznych zdecydowanie nie można ich zaliczyć do Semitów, choć judaistyczne korzenie ich religii są niepodważalne ${ }^{3}$. Odwołując się do Pięcioksięgu Mojżesza, używając alfabetu i języka hebrajskiego nie tylko w literaturze sakralnej oraz zachowując orientalne elementy kultury, mogli być uznawani potocznie za Żydów ${ }^{4}$.

Przybycie Karaimów związane było z polityką wielkiego księcia Witolda (ok. 1350-1430) i jego zaangażowaniem wojennym w rejonie Półwyspu Krymskiego. Nie można wykluczyć możliwości, że pierwsi Karaimi znaleźli się wśród jeńców, jakich sprowadził na Litwę książę Witold po nieudanej wyprawie i przegranej bitwie pod Worsklą 12 sierpnia 1399 r. ${ }^{5}$

pedia, vol. 10, s. 311; Jüdisches Lexikon, Bd. IV/2, kol. 1058-1059; Karaite Encyclopedia, Frankfurt am Main 1995, s. 280-282; R. Tenberg, Isaak ben Abraham, w: BiographischBibliographisches Kirchenlexikon, Bd. 2 (1990), kol. 1349-1351; L. Nemoy, Troki, Izaac ben Abraham, w: Encyclopedia Judaica, vol. 20 (2007; second ed.), 155-156.

2Por. A. Zajączkowski, Ze studiów nad zagadnieniem chazarskim, Prace Komisji Orientalistycznej PAU, t. 36 (1947), s. 3-99; T. Nagrodzka-Majchrzyk, Nowe Chazarica, Przegląd Orientalistyczny, 1986 nr 133-134, s. 247-251; G. Rostkowski, Międzynarodowe $i$ wewnętrzne położenie kaganatu chazarskiego $w$ pierwszej połowie $X$ wieku, Mazowieckie Studia Humanistyczne, t. 6:1-2 (2000), s. 5-24; W. Kefeli, E. Lebiediewa, Karaimy - drevnij narod Kryma, Symferopol 2003.

3Por. T. Czacki, Rozprawa o Żydach i Karaitach, Wilno 1807; J. Fürst, Geschichte des Karäertums, Bd. 1-3, Leipzig 1862-1869; Bohdan Janusz, Karaici w Polsce, Kraków 1927; A. Dubiński, Caraimica. Prace karaimoznawcze, Warszawa 1994; Sz. Szyszman, Karaimizm. Historia i doktryna, Wrocław 2005.

${ }^{4}$ Por. R. Mahler, Karaimer. A Yidishe geule-bavegung in Mitlalter, Nyu-York 1947 (w jidysz); tegoż, ha-Kara'im. Tenu'at-ge'ulah Yehudit bi-Yeme ha-Benayim [Karaimi. Na ratunek średniowiecznemu ruchowi żydowskiemu], Merhavyah 1949; A. Zajączkowski, Karaims in Poland. History, language, folklore, science, Warszawa 1961; A. Backer, Di Karaimer. Historisher iberblik, Tel-Aviv [1990] (w jidysz); J.-F. Fau, Les Caraîtes, Turnhout, 2000; G. Pełczyński, Karaimi polscy, Poznań 2004; S. Gąsiorowski, Relacje karaimsko-żydowskie w dawnej Rzeczypospolitej (XV-XVIII w.), Kwartalnik Historii Żydów, 2003, nr 3 (207), s. 444-450.

5Por. L. Kolankowski, Problem Krymu $w$ dziejach jagiellońskich, Kwartalnik Historyczny, t. 49 (1935), s. 279-300; J. Tyszkiewicz, Karaimi litewscy w czasach Witolda i sprawa przywileju datowanego rokiem 1388, Studia Źródłoznawcze, t. 36 (1997), s. 45-65; tegoż, Karaimi na Rusi i Litwie do roku 1388, Przegląd Orientalistyczny, 1999, nr 3-4, s. 177-186. 
Najstarszym centrum osadnictwa karaimskiego były Troki ${ }^{6}$ a później Karaimi osiedlili się także w innych miastach Litwy (Birże, Poniewież, Szawle, Poswol), na Wołyniu (Łuck)7, na Rusi Czerwonej (Lwów ${ }^{8}$, Halicz$^{9}$, Kukizów - Krasny Ostrow ${ }^{10}$, Żółkiew) i Podolu (Derażne). Wydaje się, że najważniejszą i najsilniejszą gminą, nawet po przyłączeniu Rusi i Ukrainy do Korony w 1569 r., pozostawała wspólnota trocka ${ }^{11}$. Taką pozycję zachowała przez cały okres istnienia Rzeczypospolitej. Z czasem Karaimi troccy wyjednali u króla Władysława IV Wazy przywilej z 3 grudnia 1646 r., na mocy którego zakazano Żydom osiedlać się w Trokach oraz prowadzić handel w tym mieście. Przepisy te nie były przestrzegane, a Żydzi stopniowo osiedlali się w Trokach. W 1680 r. mieszkało w Trokach 30 rodzin karaimskich i prawdopodobnie jedna żydowska, zaś w 1765 r. - 300 Karaimów i 150 Żydów.

Wielki książę litewski Kazimierz Jagiellończyk (od 1447 r. król Polski) na mocy swego przywileju z 27 marca $1441 \mathrm{r}$. nadał gminie trockiej, nazwanej w dokumencie Żydami trockimi, prawo magdeburskie, „ze względu na szkody, jakie w tym czasie ponieśli” oraz „aby byli w stanie podnieść się z tak wielkiej biedy”, w jakie się wówczas znaleźli. Od tej pory mieli „posiadać i przestrzegać (...) wszystkich klauzul artykułów" prawa magdeburskiego w taki sposób, jak było ono zachowywane w innych miastach litewskich. Od tego momentu mieli

${ }^{6}$ B. Janusz, Karaici w Polsce, s. 87-92; M. Nadav, Troki, w: Encyclopedia Judaica, vol. 20 (2007, second ed.), 154-155; J. Sobczak, Osadnictwo karaimskie w Wielkim Księstwie Litewskim, Sprawozdania PTPN Wydz. Hist. i Nauk Społ., 1988, s. 55-58; P. Borawski, Zwyczaje i obrzędy religijne Karaimów litewskich, Acta Baltico-Slavica, 1990, s. 265-295.

7J. Poczobot, Przyczynek do historii Karaimów w Łucku, Łuck 1908 (Jednodniówka Łucka); J. Smoliński, Karaimi i bóżnica ich w Łucku, Ziemia, 1912, nr 3-8, 22; B. Janusz, Karaici w Polsce, s. 92-96; A. Zajączkowski, Karaimi na Wołyniu, Rocznik Wołyński, t. 3 (1934), s. 149-191.

8Por. St. Kunasiewicz, Przechadzki archeologiczne po Lwowie, Lwów 1876, s. 122; J. Caro, Geschichte der Juden in Lemberg, Krakau 1894, s. 1-3.

9Por. G. Smólski, U Karaimów w Haliczu, Naokoło świata, Warszawa 1903; Bohdan Janusz, Karaici w Polsce, s. 96-103; Z. Abrahamowicz, Dzieje Karaimów w Haliczu, wyd. S. Gąsiorowski, Przegląd Orientalistyczny, 2001, nr 1-2; S. Gąsiorowski, Karaimi w Haliczu $w$ świetle polskiej historiografii, w: Karaimi Hałycza. Istorija ta Kultura. Materiali miżnarodnoj konferencji, Hałycz, 6-9 weresnja 2002, Lviv - Hałycz 2002; przybycie Karaimów do Halicza wiązane jest niekiedy z osobą księcia Daniela Halickiego (1201-1264).

${ }^{10}$ Por. B. Janusz, Karaici i cmentarzysko ich, Ziemia. Tygodnik krajoznawczy ilustrowany, R. 2 (1911), nr 1, s. 3-7; S. Gąsiorowski, Karaimi w Kukizowie. Rekonesans badawczy, w: Żydzi i judaizm we współczesnych badaniach polskich, t. 2: Materiały z konferencji, Kraków 24-26 XI 1998, red. K. Pilarczyk, S. Gąsiorowski, Kraków 2000, s. 73-81.

11B. Janusz, Karaici w Polsce, Kraków 1927, s. 45-53; por. T. Kowalski, Karaimische Texte im Dialekt von Troki. Eingeleitet, erläutert und mit einem karaimisch-polnischdeutschen Glossar versehen (Teksty karaimskie w narzeczu trockim z wstępem i objaśnieniami w języku niemieckim, tudzież ze słownikiem karaimsko-polsko-niemieckim), Warszawa 1929 (Prace Komisji Orientalistycznej, nr 11); Leizar Krasnosselsky, Zur Geschichte der Karäer im russische Reiche. Inaugural-Dissertation der hohen philosophischen Fakultär der Universität Bern zur Erlangung der Doktorwürde, Bern 1912. 
oni podlegać wójtowi, a tenże wójt miał odpowiadać tylko przed majestatem królewskim. Do najważniejszych obowiązków wójta należało sprawowanie sądów w sprawach dotyczących gminy karaimskiej, chyba że doszło do sporu z Litwinem (katolikiem?), Rusinem (prawosławnym?), albo osobą, która nie podlega prawu magdeburskiemu. Wówczas sądowi przewodził wojewoda lub jego zastępca. By polepszyć materialne położenie gminy, książę przekazał gminie „połowę dochodów z wagi i połowę dochodów z woskobojni, w której wytapia się wosk, ze wszystkimi ich korzyściami i prowentami"12. Dzięki temu dokumentowi gmina trocka uzyskała samodzielność i niezależność, co stanowiło podwaliny dla pomyślnego rozwoju w następnym wieku.

Izaak, syn Abrahama, urodził się w Trokach w 1533 r. i tamże zmarł w 1594 r. Koleje jego życia nie są dokładnie znane. Literatury hebrajskiej i znajomości Biblii uczył się pod kierunkiem karaimskiego uczonego Zefaniasza (Cefanii) syna Mordechaja, ale pobierał także nauki w chrześcijańskich szkołach, poznając bez wątpienia łacinę i język polski. W wieku około 20 lat objął obowiązki sekretarza gminy karaimskiej w Trokach i pełnił tę funkcję przez wiele lat. Służył także gminie karaimskiej i żydowskiej jako dajan, zasiadając w beit-din (sąd) oraz jako szofet (wójt) w gminie karaimskiej. W 1553 r. był także sekretarzem Va'ad Medina Lita - Najwyższej Rady Karaimów Litewskich ${ }^{13}$. By odpowiedzieć na antyżydowskie oskarżenia niektórych pisarzy i by wykazać prawowierność religii karaimskiej (mozaistycznej), Izaak pod koniec swego życia napisał swoje najważniejsze dzieło, które przyniosło mu sławę - „Hizzuk Emunah" (Twierdza wiary) ${ }^{14}$.

Ze względu na posiadaną wiedzę i umiejętności w okresie ożywionych dyskusji religijnych w Wielkim Księstwie Litewskim doby Reformacji bywał zapraszany do udziału w dysputach (tzw. kolokwiach), o czym zresztą sam wspominał we wstępie do wspomnianego dzieła. Podaje tam, że w młodości dyskutował z biskupami i możnymi tego kraju. Często bywał także zapraszany na dwory szlachty i królewskich urzędników. W konsekwencji częstych kontaktów z teologami chrześcijańskimi doskonale poznał chrześcijańską teologię i filozofię, reprezentowaną przez różne odłamy i sekty chrześcijańskie. Wykorzystując znajomość języków, zainteresował się Izaak także traktatami antychrześcijań-

12Przywilej ten został konfirmowany przez wielkiego księcia Aleksandra Jagiellończyka 17 grudnia 1492 oraz przez króla Zygmunta I Starego 23 listopada 1507; por. wydanie w Sbornik starinnych gramot i uzakonienij Rossijskoj Imperii kasatielno praw i sostajanija rusko-poddannych Karaimow, izdanie Z.A. Firkowicz, St.-Petersburg 1890, s. 7-9, 12-15; także tłumaczenie R. Mahler, E. Ringelblum, Teksty źródłowe, s. 58; J. Drabina, Wierzenia, religie, wspólnoty wyznaniowe w średniowiecznej Polsce i na Litwie i ich koegzystencja, Kraków 1978, s. 142-143.

${ }^{13}$ Por. J. Mann, Texts and Studies in Jewish History and Literature, vol. 2, New York 1972, 769-790; S. Schreier, Isaac of Troki's Studies of Rabbinic Literature, Polin, t. 15 (2002), s. 65-66.

14T. Weiss-Rosmarin, Introduction, w: הנומא קוזח. Fait Strengthened. Translated by Moses Mocatta, New York 1970, s. v-xii. 
skimi i antyżydowskimi pióra współczesnych mu autorów. Bez wątpienia znał dobrze myśl Marcina Czechowica (1532-1613)15 i Szymona Budnego (1550-1593)16. Odwoływał się też do „Kroniki świata” Marcina Bielskiego (1495-1575). Najlepiej znał i najczęściej cytował polskich autorów antytrynitarskich ${ }^{17}$. W jednym z rozdziałów swego dzieła pisze tak:

„W naszym pokoleniu wielu z ich uczonych, nazywanych w ich języku sektą Ebionitów, Sarocianistów [tj. Socyjanów], ariańską (którzy podzieleni byli na dwie: kalwinistów i Luteran) ${ }^{18}$, wierzyło w jedynego Boga i odrzucało dogmat o Trójcy, jak to uczony Niccolo Paruta napisał o jedności Stwórcy, nie będzie błogosławiony, w swojej łacińskiego księdze „De Uno Vero Deo”, co znaczy „O Jednym prawdziwym Bogu”. Podobnie pisał uczony Marcin Czechowicz w swojej polskiej księdze Rozmowy w części drugiej, odrzucał przekonanie trynitarian, opierając się na silnych dowodach zaczerpniętych z Pisma Świętego i rozumu ${ }^{19}$.

Kilka stron dalej powołuje się na opinie kolejnego uczonego:

„Chrześcijański uczony Szymon Budny w swoim dziele „Obrona” napisał, że święta Tora, dana ludowi Izraela przez Mojżesza na Górze Horeb, jest doskonała i stale zachowuje swojq ważność, oraz że nie ma innego Boskiego Prawa niż to prawo. Wszyscy ci, którzy twierdza, że sq dwie Tory, jedna Tora Mojżesza i druga Tora Jezusa, sq $w$ błędzie. Jezus nie nadał nam nowej Tory, ale sam polecił, aby Tora Mojżesza była nadał przestrzegana. [Szymon Budny - R.W.] uzasadniał to opierając się na profetycznym i racjonalnym dowodzeniu"20.

Kontakty kulturowe i teologiczne między gminami antytrynitarzy (arian), a żydowskimi (czy karaimskimi na Litwie) wydają się osobnym, niezwykle interesującym tematem badawczym.

Nie może także dziwić widoczna w pracy Izaaka rozległa znajomość literatury rabinicznej, w tym dzieł Saadji Gaona (882-942), Majmonidesa (1135-1204), Judy ha-Leviego (przed 1050-1141), Judy he-Hassida (ca. 1150-1217), czy Ra-

15Izaak cytował dzieła Marcina Czechowica, Trzech dni rozmowa o dzieciokrzczeństwie, (Łask 1578) i Rozmowy Chrystijańskie (Kraków 1575).

${ }^{16}$ Izaak cytował dzieło Szymona Budnego, O przedniejszych wiary chrystiańskiej artikułach, to jest o Bogu jedynym, o Syn jego i o Duchu Świętym, Łosk 1576; M. Bałaban, Historia literatury żydowskiej, t. 3, Warszawa-Kraków 1925, s. 159; J. Kamieniecki, Szymon Budny - zapomniana postać polskiej reformacji, Wrocław 2002, s. 134-135.

${ }^{17}$ Por. R. Dan, Isaak Troky and his „Antitrinitarian” Sources, w: Occident and Orient. A Tribute to the Memory of Alexander Scheiber, Budapest 1988, s. 69-82; J.M. Rosenthal, Marcin Czechowic and Jacob of Bełżyce. Arian - Jewish Encounters in Sixteenth Century Poland, Proceedings of the American Academy for Jewish Research, t. 34 (1966), s. 77-95.

${ }^{18}$ Informacja o podziałach teologicznych nie jest precyzyjna, co mogło wynikać $\mathrm{z}$ trudności terminologicznych.

${ }^{19}$ Izaak ben Abraham, Hizzuk Emunah, Ashdod 1975, s. 54 (tłumaczenie R.W. na podstawie angielskiego przekładu Goldy Akhiezer).

${ }^{20}$ Izaak ben Abraham, Hizzuk Emunah, Ashdod 1975, s. 78 (tłumaczenie R.W. na podstawie angielskiego przekładu Goldy Akhiezer). 
sziego (1040-1105). Cytował Talmud babiloński, Misznę, Targum Onkelos oraz Sefer ha-Mada'ot Beniamina z Tudeli21.

Dzieło „Hizzuk emunah” składa się z dwóch części: pierwsza zawiera pięćdziesiąt rozdziałów, druga - sto. Izaak rozpoczął swój wykład od zaprezentowania argumentów, że Jezus nie był Mesjaszem zapowiadanym przez Proroków. W jego opinii wykazać to można było nad postawie czterech rodzajów argumentów: (1) genealogii Jezusa, (2) czynów Jezusa, (3) epoki, w której żył oraz (4) faktu, że za życia Jezusa nie wypełniły się przepowiednie związane ze spodziewanym przyjściem Mesjasza. Izaak nie podważał szczegółowo - wątpliwych w jego mniemaniu - powiązań między Józefem i królem Dawidem, ale zadawał pytanie o powiązania między Jezusem i Józefem, który nie był wszak jego ojcem. Cytując słowa Jezusa zapisane w Ewangelii według św. Mateusza (10, 34-36), podnosił kwestię prawości jego czynów („Nie sądźcie, że przyszedłem nieść pokój na ziemię. Nie przyszedłem przynieść pokoju, lecz miecz. Bo przyszedłem poróżnić syna z jego ojcem, córkę z matką, synową z teściową ${ }^{22 ") . ~ Z ~ d r u g i e j ~ s t r o-~}$ ny Pismo Święte przypisuje oczekiwanemu Mesjaszowi czyny odmienne niż te, których dokonał Jezus. Biorąc po uwagę okres, w którym żył Jezus, można stwierdzić, że nie przyszedł on w czasie zapowiadanym przez proroków. Według ich świadectwa Mesjasz miał przyjść w „ostatnich dniach” (Izajasz 2, 2). Wszyscy prorocy przepowiadali, że po przyjściu Mesjasza na ziemi zapanuje pokój i sprawiedliwość nie tylko wśród ludzi, lecz także między zwierzętami. Nawet wśród samych chrześcijan nie ma takich, którzy szczerze wierzyliby, że tak się właśnie stało.

Wiele uwagi w swoim dziele Izaak poświęcił dyskusji o kwestii boskości Jezusa. Chrześcijanie, którzy przeciwstawiają się judaizmowi, muszą wierzyć, że Jezus został umęczony i ukrzyżowany albo za swoim przyzwoleniem, albo przeciwko Jego woli. Jeśli stało się za przyzwoleniem Jezusa, to mieli Żydzi, innymi słowy, przyzwolenie na takie postępowanie. Ponadto, jeśli Jezus rzeczywiście chciał, by spotkał go taki los, to dlaczego chrześcijanie wykorzystują Ukrzyżowanie jako powód do narzekań przeciw Żydom? Jak powiązać to pytanie z modlitwą Jezusa zapisaną w Ewangelii według św. Mateusza $(26,39)$ ? Z drugiej strony, jeśli przyjmiemy, że Jezus został ukrzyżowany wbrew swej woli, jak zatem może być traktowany jako Bóg, skoro nie był w stanie przezwyciężyć władzy tych, którzy zaprowadzili go na Golgotę? Izaak pytał, jak można traktować jako Zbawiciela kogoś, kto nie zdołał uratować własnego życia? („Hizzuk Emunah", rozdział 47). W innych rozdziałach zastanawiał się, na mocy jakiego prawa chrześcijanie zamienili święty dzień Szabatu na pierwszy dzień tygodnia, co nie było polecane ani przez Jezusa, ani przez jego uczniów.

W kolejnych rozdziałach części pierwszej Izaak wypowiadał się o historii chrześcijaństwa (rozdział II), o rozmowach $\mathrm{z}$ duchownym prawosławnym

${ }^{21}$ S. Schreier, Isaac of Troki's Studies of Rabbinic Literature, Polin, t. 15 (2002), s. 68-69.

${ }^{22}$ Cytat według Pismo Święte Starego i Nowego Testamentu (Biblia Tysiąclecia), Poznań - Warszawa 1987, s. 1135. 
(rozdział III), z duchownym luterańskim (rozdział IV), z uczonym chrześcijańskim (rozdział VI). Większość rozważań w tej części poświęcona jest jednak filologicznej interpretacji hebrajskich terminów używanych w żydowskiej Biblii (np. w rozdziale IX wypowiada się o właściwym przekładzie słowa Elohim z Księgi Rodzaju 1,1). Część druga poświęcona jest krytycznej analizie Nowego Testamentu w oparciu o wydany w 1572 r. przekład Szymona Budnego. W stu krótszych - w porównaniu do części pierwszej - rozdziałach Izaak wyszukuje sprzeczności w poszczególnych fragmentach Nowego Testamentu i rozbieżności ze Starym Testamentem.

Izaak z Trok zmarł przed ukończeniem prac nad swoim dziełem. Spis treści, wstęp oraz prawdopodobnie układ drugiej części został dokończony przez jego ucznia Józefa Malinowskiego syna Mordechaja z Trok. „Hizzuk Emunah” przez wiele dziesięcioleci pozostawała w rękopisie, a jej tekst doświadczył wielu zmian w trakcie przepisywania przez kopistów. Niekiedy rabini zastępowali wręcz argumenty Izaaka wypływające z przesłanek filozoficznych na argumenty talmudyczne. Drukiem dzieło Izaaka ukazało się najpierw w łacińskim przekładzie dokonanym przez orientalistę i polihistora Johanna Christopha Wagenseila, profesora uniwersytetu w Altdorf w Niemczech i zamieszczonym w jego dziele Tela Ignea Satanae. Hoc est arcani et horribiles Judaeorum adversus Christum Deum et Christianam religionem libri („Płomienne strzały szatana, to jest tajemne i przerażające księgi żydowskie przeciwko Chrystusowi, Bogu i wierze chrześcijańskiej”), wydanym w Altdorfie w 1681 r. Tom ten był następnie kilka razy przedrukowany, między innymi w Amsterdamie w 1705 r., w Jerozolimie w 1845 r. i w Lipsku w 1857 r. W Amsterdamie w 1717 r. ukazało się tłumaczenie na język judeo-niemiecki. W Sohrau w 1865 r. wydrukowano przekład na literacki niemiecki dokonany przez Dawida Deutscha ${ }^{23}$. W 1873 r. wydano ten ostatni przekład po raz drugi wraz z tekstem hebrajskim. W XIX w. Moses Mocatta (1768-1857), bogaty londyński handlowiec, który połowę swego życia poświęcił studiom żydowskim, dokonał pierwszego tłumaczenia na język angielski. Jego przekład ukazał się w Londynie w 1851 r., choć na stronie tytułowej znajduje się informacja Printed But Not Published ${ }^{24}$. Mocatta zaznaczył w ten sposób niejasną pozycję Żydów w Anglii, gdyż dopiero w 1855 r. Żydzi angielscy otrzymali pełne prawa obywatelskie. Przekład hiszpański „Fortificaión de la Fe” dokonany został w 1621 r.25, lecz pozostawał on w rękopisie przez wiele dziesięcioleci.

${ }^{23}$ Chizzuk Haemunah. Befestigung im Glauben, herausgegeben mit verbessertem hebräischem Texte ... von David Deutsch, Sohrau 1865; Sefer Hizuk emunah. Befestigung im Glauben, mi-R. Yitshak be-R. Avraham, huva el bet ha-defus me-hadash be-hagahah meduyeket ..., ve-nilvah la-zeh haatakat ha-sefer li-leshon Ashkenaz ve-od ezeh hearot mimeni David ben Mordekhai Daitsh, Sohrau, Selbstverlag des Herausgebers, Breslau 1873.

${ }^{24}$ Isaac ben Abraham Troki, Faith strengthened, translated by Moses Mocatta, introduction by Zeev Peter Breier, Jerusalem 1999.

${ }^{25}$ A. Geiger, Isaak Troki. Ein Apologet des Judenthums am Ende des 16. Jahrhunderts, w: Nachgelassene Schriften, Bd. 3, Berlin 1876, s. 209. 
Warto pokreślić, że do dziś brakuje krytycznego wydania „Hizzuk Emunah”, a autorzy przekładów (np. David Deutsch i Moses Mocatta) nierzadko parafrazowali tekst napisany przez Izaaka. Mocatta w wstępie stwierdził, że niekiedy wręcz opuszczał fragmenty tekstu, w których Izaak w sposób - według niego przesadny - powtarzał te same argumenty lub cytaty, którymi tekst oryginalny jest przeładowany.

Simcha Izaak Łucki (zm. 1776), syn Mojżesza ${ }^{26}$, urodzony w Łucku karaimski pisarz i bibliograf, wymienia jeszcze dwa inne dzieła Izaaka: traktat o fazach księżyca oraz dialog o uboju zwierząt. Izaak miał także ułożyć pieśni liturgiczne, a niektóre z nich zostały włączone do karaimskich modlitewników (Siddurim) ${ }^{27}$.

Jak można było się tego spodziewać, wkrótce po wydaniu w $1681 \mathrm{r}$. Tela ignea Satanae w środowisku uczonych chrześcijańskich ukazały się traktaty polemiczne z tezami Izaaka z Trok i jemu pokrewnych uczonych ${ }^{28}$. W 1699 r. światło dzienne ujrzało pierwsze bodaj dzieło tego typu, autorstwa protestanckiego orientalisty Rudolfa Martina Meelführera, zatytułowane Jesus in Talmude („Jezus w Talmudzie”). Polemizował on z opiniami o Chrystusie, jakie zawarte zostały w różnych fragmentach Talmudu, a później cytowane były przez antychrześcijańskich polemistów. Niestety, dzieło Meelführera nie zdobyło sobie uznania i szybko zostało zapomniane. 0 wiele większe znaczenie miała kolejna książka napisana po niemiecku przez Johanna Andreasa Eisenmengera, a zatytułowana Entdecktes Judenthum („Zdemaskowany judaizm”), która przez wiele dziesięcioleci pozostawała głównym źródłem argumentów dla antyżydowskich i antysemickich oskarżeń.

Równie często na to dzieło powoływali się wolnomyśliciele (masoni). Dzieło to znał i cytował francuski filozof Wolter, choć o samym autorze nie wypowiadał się z uznaniem ${ }^{29}$.

26Por. W. Zajączkowski, Łucki Sima Izaak (zm. 1776), w: -Polski Słownik Biograficzny, t. 18 (1973), z. 4, s. 513.

27J. Fürst, Geschichte des Karäertums, Bd. 3, s. 30 i nn.; A. Neubauer, Aus der Petersburger Bibliothek. Beiträge und Documente zur Geschichte des Karäerthums und der karäischen Literatur, Leipzig 1866, s. 64; A. Geiger, Nachgelassene Schriften, s. 178-224, Berlin, 1876; Gottlober, Bikkoret le-Toledot ha-Kara'im, Vilna 1865, s. 184; H. Grätz, Geschichte der Juden, Bd. 9, Breslau 1907 (4 Auflage), s. 490.

${ }^{28} \mathrm{~J}$. Gousset, Jesu Christi Evangeliique veritas salutifera, demonstrata in confutatione libri Chizzouk emounah a R. Isaco scripti, in qua pleraque Judaeorum adversus doctrinam Christianam argumenta, aut difficultates, pleraeque in Novi Testamenti loca censu rae examinantur ac diluuntur ..., accedunt eiusdem auctoris in Epistolam ad Hebraeos, et ad Levit. XVIII, 14 disputationes sex., Amstelodami 1712; także żydowscy autorzy wykorzystywali argumenty Izaaka z Trok przeciwko działalności chrześcijańskich misjonarzy; por. F. de Sola Mendes, Defence, not defiance. A Hebrew's reply to the missionaries, New York 1876.

${ }^{29}$ Por. H. Emmrich, Das Judentum bei Voltaire (Sprache und Kultur der germanischromanischen Völker. C. Romanistische Reihne, Bd. 5), Breslau 1930, s. 221-224; tam cytat z Woltera: Il a rassemblé toutes les difficultés que les incrédules ont prodiguées depuis. Enfin les incrédules les plus determinés n'ont presque rien allegué qui ne soit dans 
Izaak z Trok wykazywał się doskonałą znajomością literatury rabinicznej. Trudno jednoznacznie określić formy i zakres kontaktów między gminą żydowską i karaimską w tym okresie. Mimo różnic religijnych wydaje się, że te kontakty, przynajmniej w przypadku Izaaka i kilku innych uczonych, były częste. Warto zwrócić uwagę na dokument z 1475 r. spisany we Lwowie, na mocy którego Karaimi mieszkający na przedmieściu, zwolnili „na zawsze i na wieki” Żydów rabanitów od „wszelkich straży, robót, danin, od robót około skór” i innych powinności. Podobnie uczynili wobec Karaimów Żydzi rabanici, co starsi obu gmin poprzysięgli przed sądem ${ }^{30}$. W tej zapisce sądowej pojawiła się też po raz pierwszy użyta nazwa własna „Caraymowie” 31 .

Oprócz Izaaka z Trok w gminie karaimskiej działało kilku innych uczonych, którzy częściowo kontynuowali jego pracę. Józef Malinowski, syn Mordechaja był karaimskim uczonym, który żył w Trokach w XVI w. ${ }^{32}$. Jak wspomniano wyżej, był on uczniem Izaaka z Trok i przygotował wstęp oraz indeks do „Hizzuk Emunah”. Był także autorem kilku dzieł, w tym zbioru modlitw „Ha-Elef Leka”, wydanego w Amsterdamie ok. 1626 r., „Chizzur 'Inyan Shechitah” zawierającego rozważania o uboju zwierząt wraz z komentarzami karaimskiego hachama Eliasza Baszjaci (ok. 1420-1490), wydanymi razem z „Dod Mordechaj” Mordechaja ben Nisana ${ }^{33}$ w Wiedniu w 1830 r. Simcha Łucki przypisywał mu także autorstwo „Sefer Minhagim”, księgi opisującej zwyczaje rytualne karaimów, „Perush 'al Hachdamat Azulah” - komentarzy do modlitwy „Azulah”, zawierającej artykuły wiary według wyznania karaimskiego oraz „Perush 'al 'Inyan ha-'Arayot”.

Innym karaimskim uczonym żyjącym w Trokach na przełomie XVII i XVIII w. był Salomon syn Arona. Był on krewnym Mordechaja, syna Nisana, autora dzieła „Dod Mordechai”, który budził podziw współczesnych znajomością literatury rabinicznej i przedmiotów świeckich. Salomon sam był autorem „Migdal 'Oz”, antychrześcijańskiego dzieła polemicznego w siedmiu rozdziałach. Inny jego utwór zatytułowany „Rak we-Tob” dotyczył sporów między Karaimami a Żydami rabbanitami i ułożony był w formie dialogu. Tego samego zagadnienia dotyczyło dwutomowe dzieło „Lehem Se’orim”. Pierwszy tom „Rehaba’am ben Shelomoh" z serii „Appiryon” prezentował poglądy Karaimów na religię żydowską, drugi zaś tom, „Yarabe’am ben Nebat”, krytykował chrześcijańskie dogmaty. To ostatnie (obszerne) dzieło przechowywane jest w rękopisie w Petersburgu

le Rempart de la Foi du rabbin Isaac; por. też J. Szechtman, Voltaire o Hizzuk Emunah, Jewish Quarterly Review, vol. 48 (1957), s. 53-57.

${ }^{30}$ M. Bałaban, Żydzi lwowscy na przełomie XVI-go i XVII-go wieku, Lwów 1906, s. 6; R. Mahler, E. Ringelblum, Teksty źródłowe, s. 36; J. Drabina, Wierzenia, religie, wspólnoty wyznaniowe w średniowiecznej Polsce i na Litwie i ich koegzystencja, s. 143; tegoż, Religie na ziemiach Polski i Litwy w średniowieczu, wyd. J. Drabina 1989, s. 189-190.

${ }^{31}$ B. Janusz, Karaici w Polsce, Kraków 1927, s. 13.

32J. Fürst, Geschichte des Karäertums, Bd. 3, s. 37; M. Steinschneider, Catalogue of the Hebrew Books in Bodleian Library, Berlin 1852, kol. 1509; W. Zajączkowski, Malinowski Józef (w. XVI/XVII), w: -Polski Słownik Biograficzny, t. 19 (1974), s. 345-346.

${ }^{33}$ W. Zajączkowski, Mordechaj ben Nisan (w. XVII-XVIII), w: -Polski Słownik Biograficzny, t. 21 (1976), s. 764. 
(St. Petersburg, Ms 754 i 755). Jest ono świadectwem rozległej znajomości literatury rabinicznej autora. Salomon wspominał innych uczonych działających w Wielkim Księstwie Litewskim w jego czasach. Wyszczególnił także tytuły karaimskich dzieł będących w posiadaniu Josefa Salomona Delmedigo (15911655). Jeden z rozdziałów tego rękopisu dotyczył także nauczania i objaśniania religijnych zwyczajów Karaimów. W innym utworze Salomon odpowiadając na pytanie jednego z szwedzkich ministrów, który interesował się początkami religii karaimskiej, wyliczał różnice między karaimami i Żydami rabbinitami oraz opisywał przepisy liturgiczne karaimów. To ostatnie dzieło, znane także pod tytułem „Appiryon”, zostało wydane drukiem przez A. Neubauera 34.

Około 1580 r. urodził się w Trokach Zarach (Serah) syn Natana. Korespondował on z Josefem Salomonem Delmedigo na tematy dotyczące matematyki, astronomii, Kabały oraz z Meirem z Metzu. Listy te zebrał i przygotował do druku Abraham Geiger (1810-1874) pod tytułem "Miktab Ahuz" w swoim zbiorze "Melo Chofnajim". Zarach ułożył także kilka utworów liturgicznych, z których dwa zostały włączone do karaimskiego modlitewnika (Siddur) ${ }^{35}$.

Ciekawie przedstawia się opinia Josefa Salomona Delmedigo o litewskich Karaimach. Przebywał przez pięć lat na dworze księcia Krzysztofa Radziwiłła jako nadworny lekarz i dobrze poznał litewskie środowisko. W swoich listach podkreślał, że najlepiej wykształconymi ludźmi (także w przedmiotach świeckich), jakich spotkał na Litwie, byli Karaimi. Żydzi rabanici mieli rozprawiać tylko o Talmudzie, a ich wiedza nie wykraczała poza talmudyczne rozprawy. Delmedigo przybył na Litwę już po śmierci Izaaka z Trok, ale mógł spotkać jeszcze ludzi z jego kręgu albo jego naśladowców ${ }^{36}$.

Innym spośród zasłużonych autorów karaimskich żyjących w Trokach w XVI w., był Abraham syn Arona, hazzana trockiego. Sławę zdobył jako poeta i autor utworów liturgicznych, które później zostały włączone do modlitewników ${ }^{37}$.

Z Trok pochodził także Abraham syn Jozjasza ha-Szofeta. Był lekarzem i przebywał na dworze króla Jana III Sobieskiego. Pozostawił po sobie dwa dzieła medyczne, jedno w języku hebrajskim zatytułowane „Ozar ha-am”, drugie po łacinie, które nadal pozostaje w rękopisie (St. Petersburg Cat., nr 732). Według Abrahama Firkowicza (1786-1874) ${ }^{38}$ był on też autorem innego dzieła, liczącego siedem rozdziałów, a zatytułowanego „Masa ha-am”, które po przetłumacze-

${ }^{34}$ A. Neubauer, Aus der Petersburger Bibliothek, s. 79; J. Fürst, Geschichte des Karäertums, Bd. 3, s. 80 i nn; Gottlober, Bikkoret le-Toledot ha-Kara'im, s. 201; B. Janusz, Karaici w Polsce, s. 36.

35J. Fürst, Geschichte des Karäertums, Bd. 3, s. 28; Gottlober, Bikkoret le-Toledot haKara'im, s. 165; Geiger, Melo Chofnayim, Berlin 1840, s. XXXVII.

36Por. S. Schreiner, Josef Shelomo Delmedigos Aufenhalt in Polen-Litauen, w: Geschichte und Kultur der Juden in der Renaissance. Neue Wege der Forschung, ed. G. Veltri, Leiden 1999; fragmenty listów Delmedigo zostały opublikowane w prace J. Mann, Texts and Studies in Jewish History and Literature, vol. 2, New York 1972; tu s. 676 i nn.

37J. Fürst, Geschichte des Karäertums, Bd. 3, s. 37.

38Por. A. Zajączkowski, Firkowicz Abraham, syn Samuela (ok. 1786-1874), w: -Polski Słownik Biograficzny, t. 6 (1948), z. 30, s. 472-473. 
niu na łacinę sam sprzedał dominikanom wileńskim ${ }^{39}$. Simcha Łucki przypisuje mu autorstwo dwóch innych dzieł: „Bet Abraham” i „Pas Yeda”, traktujących o kwestiach naukowych. Abraham syn Jozjasza ha-Szofeta zmarł w Trokach w grudniu $1688 \mathrm{r}^{40}$.

Pozostaje wyrazić nadzieję, że dzięki stopniowemu odradzaniu się studiów nad przeszłością Karaimów polsko-litewskich uda się odpowiednio do tego przygotowanym uczonym przygotować polski przekład „Hizzuk emunah” i opatrzyć go wyczerpującymi komentarzami.

${ }^{39}$ Por. uwagi W. Syrokomli, Wycieczki po Litwie w promieniach od Wilna, Wilno 1857, s. 83: Syn Jozjasza, Abraham, lekarz jednego z panów polskich, zmarły kiedyś we dworze Surdaku, napisał wyborna jak świadczy notatka, księgę po hebrajsku pt. Massa Ha'am (Trudność rzq̨dzenia narodem). Rozgniewany na Karaimów za jakowąś krzywdę ojcu jego wyrządzonq, nie oddał im swojej księgi, lecz, jak świadczy piśmienna tradycja, przełożywszy na język łaciński, sprzedał ja jezuitom. Dzieło jego, które i w oryginale i w tłumaczeniu nie wydane drukiem zaginęło.

${ }^{40}$ J. Fürst, Geschichte des Karäertums, Bd. 3, s. 94; Gottlober, Bikkoret le-Toledot haKara'im, s. 151; A. Neubauer, Aus der Petersburger Bibliothek, s. 72. 